\title{
La palabra
}

\author{
Piedad Solans
}

"El único medio de pagar la falta de escribir es aniquilar lo que se escribe.»

Georges Bataille

«¿Y cuál es la utilidad de un libro?», pensó Alicia, «¿sin imágenes ni conversación?" ¿Para qué sirve un libro sin imágenes y sin conversación? Para nada. Quizás fue Lewis Carroll uno de los primeros escritores en plantear, ya en 1871, el carácter de inutilidad de una obra, iniciando sin saberlo ni proponérselo el planteamiento de "el Arte por el Arte» que atravesaría toda la centuria posterior: el arte como creación. Pues la fragmentación -aquéllo que escinde las imágenes y los signos de su significados, abismándolos y multiplicándolos - lugar común y hasta recurso formal y artificio en la Posmodernidad, empezó a producir sus fisuras desde «el otro lado del espejo» con poetas como Baudelaire y Mallarmé, escritores como Carroll y más tarde, Joyce y Apollinaire. «El otro lado del espejo» es la «otra» realidad: aquélla que mana de la imaginación, del erotismo, de los sustratos de los mitos, de las sustancias elementales, de los terrores, de la muerte, del mundo onírico y de los sueños. Una realidad secreta y subterránea, aparentemente satánica por su transgresión, pero liberadora, pues devuelve al arte su «alter ego», sus estratos antropológicos y abismales por debajo de las capas congeladas donde la palabra y la imagen habían establecido su "lugar" como superficie y envoltura. Una realidad oculta y un magma que amenza con estallar, con rebelarse y asaltar, por las grietas incontroladas, el mundo de la objetividad a través de la incongruencia, de la sinrazón, del disparate: un absurdo que anula la estructura lógica del pensamiento, lo desenmascara y lo reduce, visible, al fin que le fue dado por la burguesia: la utilidad.

Arrasar el sistema codificado de los conceptos, romper las relaciones entre las palabras y las cosas, entre las palabras y la sintaxis, volcar el mundo al revés y vaciar los signos de sus significados..., ¿acaso no sería retornar al Origen, al sentido mágico del lenguaje como culto, arrancarlo 
de la charlatanería que lo transforma vaciedad y lo convierte en «mero signo" "? Tanto la creación literaria de los "maudits" como la empresa artística de las vanguardias a principios de siglo estará atravesada por un mito subterráneo: el del Origen. No como un retorno, sino como la constatación de una presencia. No como una nostalgia, sino como la creación de un lenguaje nuevo, un lenguaje pre-lógico, que con-tacte la escritura y la imagen con un sentido cósmico y a la vez, profundamente social y cultural.

Y para llegar al Origen, es necesario des-estructurar los signos, des-articular las asociaciones entre las palabras y mostrar el nombre, la letra: el fragmento, antes de ser abolido por la Totalidad. Extraerlo del espesor con que ha sido elaborado el mundo y arrojarlo a un vacío -el de la página- como única señal posible de generación e identidad.

«Primero la sentencia», dice la Reina, «el veredicto después» 2. Provocar el desconcierto. Crear otro mundo donde los actos cotidianos, lo acostumbrado, se vuelva del revés: donde lo real no es ya lo que se afirma, legitimado, como la materia y el ser, sino su negación: la imagen del espejo, el vacío, el no-ser. $Y$ no es un capricho, un juego formal de una burguesía que se aburre, un proyecto de desocupados intelectuales, sino una necesidad asfixiante, por su urgente transgresión y abismamiento demoníaca, de libertad.

Si la palabra en un principio era la magia, el Fonema y el Verbo secreto que horadaba la mudez de la naturaleza y de los seres, y establecía la conexión y el conducto con el misterio, el poeta debe recuperar este sentido, ex-trayéndola de su destino como signo encerrado en la estructura del espacio y la síntaxis. ¿Cómo? Rompiendo la estructura: la sucesión lineal de las palabras, el carácter narrativo del texto, la verosimilitud de lo representado: destruir el orden. No necesariamente hacia un caos, sino abriendo direcciones hacia otra visualidad, extendiendo otros espacios y alzando otros ritmos y sonidos, otros silencios donde el sujeto eleve su voz. Pues el mundo como representación, como señala Foucault, deja de ser válido como reflexión filosófica para intentar la reflexión en torno al modo de ser del hombre: el propio hacedor. La pregunta, así, ya no sería “¿Qué dice el lenguaje?" sino «¿Qué relación hay entre el ser y el lenguaje?» ${ }^{3}$. $Y$ de esta tarea, habría de apropiarse el arte.

1 WALTER BENJAMIN, "Sobre el lenguaje en general y sobre el lenguaje de los humanos", págs. 71-72, en «Para una crítica de la violencia y otros ensayos", lluminaciones IV, Taurus Humanidades, Madrid 1991.

2 LewIS CARROL, «Alicia en el País de las Maravillas», Alianza Ed., Barcelona 1991.

3 Michel Foucault, "Las palabras y las cosas", pág. 326, FCE, México. 


\section{LA TRANSGRESIÓN DE LOS LENGUAJES. EL LIBRO DE ARTISTA EN EL SURREALISMO}

«La colombe poignardée et le jet d'eau», poema perteneciente a la serie Caligrammes, compuesta por Guillaume Apollinaire entre 1914 y 1918, supuso una de las más líricas y subversivas páginas "escrita" por los poetas surrealistas del momento. Pues toda la estructura del poema está sujeta a movimiento, y es el ritmo quien marca, a través de los espacios, de los caracteres, de los tamaños y grosores de las letras, de la dirección circular o lineal que adoptan las frases, de sus separaciones y encuentros..., la lectura vibrátil y emocional de la poesía. Las letras ya no actúan como «meros signos», sino que destacan su misterio como signos: silencios, vacilaciones, preguntas y sonidos albergan y articulan los significados.

Apollinaire rompe así con la página como sucesión lineal de palabras escritas y leídas de izquierda a derecha: un orden. La ruptura con esta linealidad (que es la "linealidad" cultural dada al tiempo y al pensamiento) supone una revolución en el sistema de escritura occidental, si exceptuamos la Poesía Barroca, que ya en el siglo XVII rompió, por otros motivos, la estructura y la disposición espacial de las palabras en la página. Asimismo, la emoción, controlada por los márgenes de la página, se desborda y brota, adoptando las formas y canales simbólicos y expresivos de su fluir. La manera en que se componen visualmente los Calligrammes está en estrecha relación con la manera en que es sentida la poesía. El ojo, la palabra y la voz son uno; unidos están el ritmo, el silencio y la emoción. La narración rompe su fuerte estructura de bloque cerrado para abrise a un universo puramente lírico, donde las formas no se organizan como sintaxis en función de una representación, sino en función de una celebración: la del sentimiento del sujeto. Pues para el poeta y el artista surrealista no es la razón, sino la imaginación, el sentimiento y la emoción el magma y la resonancia misteriosa donde se origina y sucede el munclo. La sucesión lineal de las palabras es demasiado monótona, excesivamente rígida, para los ritmos constantemente alterados de la existencia. Pues la muerte, el anhelo, la nostalgia, la distancia, el pánico o el amor..., ¿cómo ser expresados, tomar cuerpo, dentro de un bloque cerrado, de una impresión que los aprieta, de una tipografía que los homologa, que convierte su explosiva "anormalidad" en norma, que contiene como un límite su esparciese, su abismarse o su reposar?

El Universo clásico se desmorona: insuficiente contención para el descubrimiento (incontenible) que hacen el poeta y el artista de su propia interioridad. 
La subversión de los modelos artísticos, sin embargo, sólo fue posible gracias al amplio campo de experimentación abierto por la tecnología. Desde la década de los años 15, los poetas y escritores surrealistas se basaron en los medios, técnicas y posibilidades de la fotografía, del cine y la tipografía para realizar y difundir su obra. Rompiendo los canales tradicionales de divulgación artística, llegaron a un público más amplio a través de periódicos, postales, carteles, octavillas, revistas y panfletos, que se conviertieron en un vehículo no sólo artístico, sino también político y fuertemente ideológico.

En 1924, la revista Surrealisme, dirigida por Ivan Goll, publica su primer número, abriéndose con un Manifiesto del Surrealismo definido por «la trasposición de la realidad a un plano superior (artístico)» ${ }^{4}$. En ella colaboran Robert Delaunay, Pierre Reverdy y el mismo Apollinaire. Pero fue André Breton quien aglutinaría todas las fuerzas del movimiento en torno a su personalidad, en el Manifiesto del Surrealismo publicado en 1924 en La Révolution Surréaliste. Revistas como Minotauro, lanzada en 1933 y dedicada a las Artes Plásticas, la música, la poesía, el teatro, la arquitectura, los estudios psicoanalíticos, la etnografía y la mitología..., hicieron posible la estrecha colaboración entre pintores, poetas, escritores, intelectuales y fotógrafos. Dirigida por Tériade, su director administrativo fue Albert Skira. En 1933, Minotauro publicó la composición fotográfica de Dali The Fenomenon of Ecstasy, dedicando también muchas de sus páginas a fotógrafos como Man Ray, Blumenfeld, Brassaï, Ubac, Fischer o Eli Lotar. Otra publicación importante fue Verve, creada por Tériada en 1937, un periódico artístico y literario que dedicó sus páginas a pintores como Picasso y Matisse, y a fotógrafos como Erwin Blumenfeld, Man Ray, Dora Maar o Brassaï, entre otros

La colaboración plástica e intelectual entre artistas y poetas fue estrecha, tanto en las ediciones de libros como en las de revistas. Pues una de las bases artísticas del Surrealismo era, como es sabido, la correlación e interacción de las diversas artes, actuando como sustratos imbricados en un mismo lugar. Bataille acompañó las fotografías de Blumenfeld para el primer número de Verve; Paul Eluard y Max Ernst publicaron Les Malheurs des Inmortels, con poemas y grabados, en 1922; Ives Tanguy ilustró con sus dibujos el libro de poemas Dormir dans les pierres, de Benjamin Péret, en 1927; André Breton prologó a Max Ernst en La femme 100 têtes, en 1929; y René Magritte realizó las ilustraciones para Breton en Qu'est-ce

4 Maurice Nadeau, «Historia del Surrealismo», pág. 72, Ed. Ariel, Barcelona 1972. 
que le Surréalisme? en 1924; Le Surréalisme et la Peinture en 1945 y los grabados para el libro de Lautréamont Les chants de Maldoror, en 1948.

Los artistas y poetas surrealistas nunca buscaron, en sus libros, una razón y un sentido entre texto e ilustración, imagen y palabra. Nada más lejos de sus propósitos ya que sus intentos se dirigieron más bien a subvertir, a través de la imaginación, del subconsciente onírico, de la asociación libre, las relaciones formales y semánticas entre la idea y su visualidad. ¿El fin? La libertad. Una libertad que no excluía, para sus propósitos, la propia inutilidad de la obra y el carácter diabólico del Mal, como había ya clamado Tristan Tzara en los Manifiestos Dadá de 1918: «Toda obra pictórica o plástica es inútil; que sea un monstruo que asuste a los espíritus serviles, y no dulzona para exornar los refectorios de animales con hábitos humanos, ilustraciones de esta triste fábula de la humanidad» 5 . Y tanto como el mal y su libertad, le imaginación, "la creación de un mundo en que el hombre encuentre lo maravilloso». La definición de la belleza fue adoptada por los artistas surrealistas en torno a la frase de Lautréamont: «Bello como el encuentro casual de una máquina de coser y de un paraguas en una mesa de operaciones", que inspiraría muchos de los Poemas-Objeto posteriores, entre ellos los de Joan Brossa. «Acoplamiento de dos realidades» diría Max Ernst, refiriéndose a la idea de Lautréamont, «en apariencia inconciliables en un plano que, en apariencia, no conviene a ninguna de las dos" ${ }^{6}$. Una muestra de ello sería, además de todas las imágenes incongruentes que utiliza el artista surrealista, este poema de Breton, publicado en el Primer Manifiesto del Surrealismo en 1924, prólogo de la poesía visual en los años setenta:

Para tener éxito con una mujer que pasa por la calle

Así, poesía e imagen surrealista son un atentado contra el principio de identidad, y en ello radica la transgresión y su libertad. Este principio, tra-

5 R. CASALÉ, "Kurt Schwitters. El Dadaísmo visto desde una óptica positiva", Arte Omega, no 14, págs. 30-33, Barcelona 1995.

6 MARIO DE M!CHELI, "Las Vanguardias artísticas del siglo XX”, pág. 184. Alianza Forma, Madrid 1979. 
dicionalmente buscado en el libro impreso entre texto e ilustración -donde el dibujo solía ser una representación alusiva, o ilustrativa, del contenido del texto- se rompe en los libros de artista surrealistas. Pero su dectrucción no conduce al nihilismo, como sucede en el Dadaísmo, sino al encuentro con otra realidad o al encuentro de realidades diferentemente manifestadas (como son la poesía y la pintura). Ello se hace especialmente patente en los libros ilustrados por Joan Miró, / était une petite pie, con textos de Lisa Hirtz, editado por Bucher en 1928, o Farler seul, con textos de Tzara, en 1948. Miró no estaba interesado en la ilustración, sino en la propia poesía como ritmo, espacios, silencios, sonidos y símbolos, es decir, en su propia e interna plasticidad. Así, la imagen pintada se convierte en una evocación lírica y mágica de la palabra, pero también, y junto con ésta, en la celebración de un Cosmos solamente advertido por la imaginación. Palabra e imagen se alejan de la representación, pues «imagen gráfica e imagen poética brotan del mismo crisol y sus afinidades las proyectan sobre el mismo espacio imaginario. El grabador ya no ilustra, se une, acompaña, anuda con él lazos más intensos (...) y yendo lo más lejos posible en la afirmación de sí mismo es como tiene más posibilidades de encontrarse con el otro, con el escritor que viene de otro allá, de abrir la unidad de un espacio donde realizar el intercambio y el acuerdo»?

La relación entre la palabra y la imagen es transgresora puesto que la página es invadida por los colores y las formas, la palabra penetra en los seres que la pueblan, y todo ello se produce en un espacio no tanto considerado como cultura sino como matriz cultural. Sonidos y signos recuperan su principio misterioso, una alusión a lo incomprensible poético, a una sensación y una memoria arcaica que se encuentra en la raíz de toda magia. Las relaciones lineales entre el universo y las cosas desaparecen, $y$ en su lugar se abre y extiende la compleja red de significados que, sutilmente, las une. La incongruencia, al fin, se convierte en un canal por donde fluyen y se revelan secretos destinos del cosmos íntimo. Pues el poeta y el artista, quizás al contrario que el filósofo, no intentan desvelar misterios, darles una explicación lógica o estructurar un sistema útil a través de la razón en que basar la existencia, sino tocar, palpar, formar cuanto surge como emoción y vitalidad, celebrándolo. Por ello, todos los Libros de Artista estarán atravesados por un principio común: la Poesía.

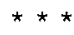

«Joan Miró. Obra gráfica». Catálogo MNCARS, Madrid, 1995. 
El Libro de Artista en el Surrealismo se produce en el ámbito, aún plano, de la página. La portada es artísticamente significativa en cuanto a que anuncia el contenido del libro, que discurrirá (al contrario que «los libros-máquina" futuristas o los «libros-objeto») en el mismo discurso. Es la apertura de un ritual poético, de un encuentro que es choque y filtración de lo maravilloso, no desprovisto de caracteres oníricos monstruosos, angustiosos y eróticos, funerarios y oscuros. La sucesión de páginas, si bien carece de la tactilidad de los libros futuristas, de las dimensiones de materialidad y espacialidad que adquirirán los libros a partir de los años 60 , siguen el hilo invisible y conductor de una historia no representativa ni narrativa. Usando el carácter de dirección propio de un libro (dirección de la escritura, de la lectura, de las páginas) en un antes y un después, palabra e imagen establecen su universo móvil, partiendo de una deformación de su identidad cultural para acercarse, precisamente, a lo real.

Un espacio en blanco evoca un silencio. Un signo es válido como señal. Una palabra es suficiente para expresar un sentimiento o conformar una imagen en el lector:

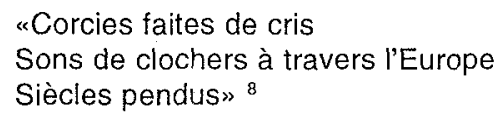

Así, Giorgio De Chirico, con las litografías que ilustran los Calligrammes de Apollinaire en 1930, sigue su propio lenguaje, casi hermético: la incongruencia entre ambos es total, y sin embargo, les une. Lo mismo ocurre con el Dictionnaire abregé de Surréalisme (1938) de Ives Tanguy, en las fotografías de Man Ray para los poemas de Paul Eluard en Facile (1935), o en las ilustraciones de dibujos de Alberto Giacometti para Poésie des mots Inconnus (1949), de Alexis Krutschonych, donde las palabras, al desdoblarse, se hacen ilegibles: como si tuvieran dos almas, pierden su identidad estática y se precipitan hacia la distorsión.

Los lenguajes son transgredidos, y sólo en esta invasión de lo prohibido existe una posibilidad de libertad.

\section{LA INVERSIÓN DE LOS CÓDIGOS. EL LIBRO DE ARTISTA DADAISTA}

DA DA. Donde señala el azar, brota una palabra y una imagen dadaísta. El encuentro es casual. La intención: el desorden. Cromos, fotografías,

8 Guillaume Apollinaire, "Calligrammes», 1930. 
recortes de periódicos y revistas, billetes de autobús... La irrupción de los materiales es tumultuosa. Cada elemento define su falta de mensaje, su desidentificación. Cada fragmento, su particular historia. Cada imagen se enfrenta a cada imagen como una contradicción. Los insectos coleópteros ocupan el mismo rango visual que un Cristo románico: los símbolos pierden sus significados. Las palabras se aglomeran: convulsiones del lenguaje. Los signos están vacíos de contenido: acumulados, se amontonan unos sobre otros, unos contra otros, anulándose, tapándose, potenciándose. Las letras son fonemas, sonidos que se extienden inútiles, monstruosamente vivos se abalanzan visualmente sobre el espectador. ¿El sentido? Ninguno. No hay sentido: es la negación del sentido. El absurdo.

$Y$ sin embargo, el caos sintáctico funciona. $O$ al menos funciona en sus propósitos, que son los de generar la provocación y la sub-versión. Una llamada violenta al desorden. O una llamada a una velada dadá, que es lo mismo que llamar al desorden. Lo que se quiere expresar, se expresa. Por ello, en Dadá la palabra va indisolublemente unida a la imagen, no como estética, sino como mensaje. La misma palabra se convierte en imagen visual, dominada también por el azar y el absurdo. Pero lo que adquiere relevancia en la grafía, además de su visualidad, es el sonido: «Para obtener una pintura "total", es necesario pintar ruidos y olores, como cantan y vomitan los borrachos» ${ }^{9}$. Una indigestión de signos y una vomitona es Dadá, un «borboteo vertiginoso» y «casi un estado de delirio». En ello, el Dadaísmo se acercó y se mezcló en numerosas ocasiones con las premisas creativas y subversivas del Futurismo, especialmente en poesía, aunque esta relación fuera negada en el Manifiesto Dadaísta de Berlín de 1918: «La vida aparece como una mezcolanza de ruidos, colores y ritmos espirituales que, en el arte dadaísta, son inmediatamente reanudados mediante los gritos y las fiebres sensacionales de su audaz psique de cada día y en toda su realidad brutal. He aquí la bien marcada encrucijada que distingue al dadaísmo de todas las demás tendencias artísticas, y sobre todo del futurismo... ${ }^{10}$ ». Sin embargo, fue a partir de la inspiración en Las Palabras en Libertad (Parole in Libertà) proclamadas por Marinetti en 1912 y expuestas en 1916 en el Cabaret Voltaire de Zurich, cuando poetas y artistas dadaístas como Hugo Ball, Hausmann y el mismo Schwitters concibieron gran parte de su poesía fonética.

$$
* * *
$$

s Carlo CarRÀ, «La pintura de los sonidos, los ruidos y los olores», Manifiesto Futurista, Milán, 1913.

to Manifiesto Dadaísta, Berlín 1918. 
Una vez más, como sucedería con todos los encuentros que realizaron las vanguardias en el período 1915-1930, la aportación de la tipografía y de la máquina fue vital para la acción propagandística de las imágenes, textos e ideas de estos movimientos. Los métodos de impresión modernos permitían producir una obra de arte múltiple, y aún más: romper la idea de obra de arte. Las páginas de los libros, de las revistas, de los periódicos, carteles, etc., fueron utilizadas tanto como espacio artístico como medio de difusión. Ello abrió nuevos canales al arte como comunicación, sacándolo de las Academias y de los Museos. Como señala Martha Wilson, el arte fue asimilado por los medios de comunicación y métodos tecnológicos hasta entonces desconocidos por los artistas, y cuya idea básica era la difusión: los artistas fueron conscientes de la enorme potencia de una página de periódico. En ningún momento se buscó una traslación de los valores artísticos tradicionales, con sus imágenes y sus códigos, ni una imitación de modelos, en las superficies que ofrecían la imprenta y los mass-media. Más bien al revés: éstas desarticularon la idea de Arte. El arte comenzó a proponerse como lectura y a conformarse como lenguaje. $Y$ en ello, la palabra irá ligada a la imagen durante toda la centuria.

Las Palabras en Libertad serían inconcebibles sin la Tipografía. Fueron concebidas como una organización -o desorganización - libre de diferentes tipos de grafías, desde palabras hasta formar frases enteras, onomatopeyas; manchas y signos de puntuación que incluia a los matemáticos, en función de los sonidos, las imágenes o las ideas que se querían expresar. Se suprime, sin embargo, toda relación entre la expresión y el pensamiento, apuntando al mundo caótico "vomitado por un borracho». Esta exaltación de la incongruencia y del desorden sintáctico, tendente a socavar y destruir los cimientos de la razón ( $\mathrm{y}$, sobre todo, de la razón burguesa y de las pruebas de irracionalidad que dió ésta en la Primera Guerra Mundial) se extendió a todas las manifestaciones poéticas dadaístas, que fueron articuladas, también, de forma plástica. Así, los poemas fonéticos de Hugo Rall, Karawane (1917), o de Raoul Hausmann, Seelenautomobile (1918), permitieron a los poetas expresar la forma abstracta lograda por los pintores:

fmsbwtözäu

pggiv - ...?mü

OFFEAHBDC

$B D Q !$ «qjyEE!

A ellos se unieron los poemas ruidistas (antecesores de Cage y Fluxus), que "describen un tranvía tal como es, la esencia del tranvía con 
los bostezos del rentista Schulze y el chirrido de los frenos ${ }^{11 » ; ~ l o s ~ p o e m a s ~}$ simultáneos, que enseñan "el entrecruzamiento de todas las cosas, mientras el señor Schulze lee, el tren de los Balcanes atraviesa el puente de Nisch y un cerdo gime en el sótano del carnicero Nuttke»; y los poemas estáticos, que transforman «las palabras en individuos; de las seis letras "madera» salen el bosque con el follaje de sus árboles, los uniformes de los guardias forestales y los jabalíes; quizás sale también una pensión Bellevue o Bella Vista».

La mayoría de estos poemas eran leídos en las caóticas, ruidosas, divertidas y agitadas veladas dadá en el Cabaret Voltaire de Zurich, fundado por Hugo Ball. La subversión se llevó a cabo a través de un lenguaje literario, y esencialmente poético. Tras la llegada del escritor berlinés Hülsenbeck, las veladas se hicieron más provocadoras, introduciendo los ritmos negros y el bombo en las representaciones. Según Hugo Ball, "a Hülsenbeck le gustaría derribar la literatura a golpes de tambor» Acompañaba los poemas simultáneos de tambor, silbatos y carracas, con la colaboración de Tzara y Janco, como en El almirante busca una casa por alquilar. En El hombre nuevo, diría: «El caos es bienvenido para quien lleva el desorden en el alma».

Más que hacia los Libros de Artista, la actividad gráfica del Dadaísmo se dirigió hacia la edición de revistas, carteles y panfletos, así como las portadas de libros. El artista dadaísta no estaba interesado en la ilustración, así como el poeta tampoco lo estaba en el poema o el texto convencional. Como he señalado anteriormente, la literatura se basó en el caos, el desorden sintáctico y la visualidad, y en esta explosión de signos las «historias» procedentes de un tipo de narración figurativa o ceñidas a unos modelos de explicación fueron violentamente rechazadas por Dadá. Si el arte había muerto, como proclamaba la pancarta de la Feria Dadá en el Berlín de 1920, esgrimida por Heartfield y Grosz, también murieron las formas de expresión en que se articulaba la cultura, y una de estas formas o soporte era el libro tradicional, con sus sistemas de texto e ilustración. Al igual que se había preconizado la creación y generalización del poema ruidista, del simultáneo y del estático, en el Manifiesto Dadaísta de 1918, debido a Hülsenbeck se reclamó "el empleo de materiales nuevos en la pintura». Así, el fotomontaje, los collages, las impresiones tipográficas, las schado-

11 lbidem. 
grafías, los rayogramas, las experimentaciones cinematográficas y el readymade, e incluso las máscaras, todo ello era articulado con la espontaneidad de la escritura automática, que (fuertemente influida por la asociación libre en el psicoanálisis) extraía del subconsciente, al azar, los procesos de creación de la obra. El mismo caos sintáctico que proclamaban los escritores era seguido por los pintores, que colaboraban también en las ediciones de libros, carteles y revistas: la mezcla de registros sin relaciones aparentes entre sí fue una de las constantes vitales de toda la obra gráfica dadaísta. Y así se muestra en las portadas de la revista dadaísta Dar Dada, fundada en Zurich por Tristan Tzara. Los dos primeros números se publicaron en 1917, y el tercero en 1918, con Raoul Hausmann como editor. Fue el órgano de expresión de los dadaístas alemanes, y evidenciaba desde el principio la intención subversiva y de desorden de Dadá.

Otras revistas dadaístas fueron Maintenant, hacia 1914, de la cual Arthur Cravan era redactor único; 291, editada en Nueva York por uno de los más poderosos galeristas y protectores del arte moderno en Estados Unidos, Alfred Stieglitz, alrededor de quien girarían artistas como Picabia o Man Ray, Gleizes y Marius de Zayas, con sus contribuciones poéticas y plásticas. Considerada la primera publicación de carácter dadaísta, 291 acogió a Picabia en su número 4 con un dibujo mecánico enfrentado a una composición tipográfica de Zayas. En 1917, Picabia funda en Barcelona la revista 391, en homenaje a Stieglitz. Publicada hasta 1924 en Barcelona, París, Zurich y Nueva York, supuso un vehículo importante de agitación cultural, alcanzando una virulencia extrema. En sus portadas se pone de manifiesto la influencia mecanicista de la plástica preconizada por Picabia en torno a la máquina. Otras pequeñas revistas en las que se difunden, hasta 1920, los manifiestos dadaístas, son Bulletin Dada, Dadaphone, Cannibale o Proverbe. Al fin, en 1919 se funda la revista Littérature por parte de Aragon, Breton y Soupault, en la que colaboraron Tzara, Valéry y Paulhan. Sus portadas eran más convencionales que las dadaístas, ya que, por influencia de Aragon y Breton, se inclinó hacia el surrealismo, atendiendo a la narratividad visual y a la información de la palabra antes que a la subversión caótica del lenguaje y de las imágenes. La última revista dadaísta fue Merz, de la que fue Schwitters uno de sus principales difusores: con él, adquirió un sentido más constructivista, como en la portada, ya en 1924, del número 89, concebida junto con El Lissitzky.

Poetas como Hülsenbeck editaron en 1920 la antología Dada Almanach y libros como Oraciones fantásticas (1916), con dibujos de Grosz y grabados en madera de Jean Arp. También Jean Arp acompañaría, con sus grabados en madera, el libro Vingt cinq poèmes, de Tzara, publicado en 1918 por la Collection Dada, de Zurich. En 1925 conoció a Schwitters 
en Berlín, y colaboró en la revista Merz. Con El Lissitzky publicó en 1925 los Ismos del Arte. La obra gráfica de Arp se movía dentro de las experimentaciones dadaístas, atendiendo a una lírica orgánica, buscando un arte «universal» que le parecía el remedio "a la división y a la discordia». Las xilografías realizadas para el libro de Hülsenbeck eran estudios de simetrías abstractas, que marcarían las constantes de su obra gráfica. Como "ilustrador", se desentendió completamente de la relación coherente entre palabra e imagen, negando una representación del texto y defendiendo la plena autonomía y capacidad lingüística de la propia forma abstracta. Muchas de estas formas fueron ejecutadas a través de dibujos generados al azar, rasgando papeles y reuniendo los trozos sin una intención determinada, en un orden diferente al de la imagen original.

Por su parte, Marcel Duchamp publicó en 1917 un libro impreso en papel de periódico - uno de los medios favoritos de los dadaístas - titulado PBT. El Ciego, en cuya portada, publicada como revista, del número 2 aparecería La Broyeuse de chocolat, uno de los objetos incoherentes duchampianos. También en El Ciego se reproduciría La Fuente, firmada por Richard Mutt, y que gracias a la imprenta salió de su "ser de objeto" para convertirse en una imagen ampliamente difundida. Por último, una de las obras más interesantes, situada entre el libro, la escultura-objeto y la caja, fue La Caja Verde, autopublicada en 1934 por el propio Duchamp bajo el nombre de Rose Selavy, y con el título La mariée mise à nu par ses celibataires, même en una edición de trescientos ejemplares. La Caja Verde, compuesta de unas cien páginas, contiene las piezas de papel producidas para que aparezcan exactamente como las notas de Duchamp para El Grand Verre: trozos de papel, reversos de sobres, diagramas, fotografías, partituras musicales..., cualquier papel que pasó por las manos de Duchamp durante el largo tiempo en que creó Le Grand Verre. Aunque ejecutado en Nueva York, las notas fueron en su mayor parte realizadas en París: ello indica el carácter de ready-made de la propia caja con sus contenidos.

La subversión de Duchamp en El Ciego, sin embargo, no se basaba tanto en el desorden sintáctico del texto o de la imagen, tan frecuente en las publicaciones dadaístas, sino en el juego con el objeto y el propio mensaje doble que encarnaba, revelado como un ataque mordaz contra las convenciones artísticas - y morales- del momento, que prohibieron, precisamente, la exposición de La Fuente en la Exhibition of Independent Painters de Nueva York. Ello fue aprovechado por el propio Duchamp - un buen jugador de ajedrez-, para contestar con una provocación al arte norteamericano: "Las únicas obras de arte que ha dado América han sido sus fontanerías y sus puentes", aprovechando para desarrollar una exaltación excéntrica del absurdo, enfrentada al buen gusto burgués, en el 
Buddha of the Bath Room, tan apreciado por Duchamp. De hecho, la Fuente actúa, lingüísticamente, como un signo que altera y desequilibra todo el lenguaje de un arte instituido.

La explosión del lenguaje dadaísta tuvo un carácter iconoclasta y marcadamente político. Para ello, se usaron todo tipo de medios, como la destrucción, la provocación, el insulto, la burla y el exabrupto. El absurdo a menudo tomó una imagen de fiesta, de circo, de frenesí. Una carcajada grotesca que arrancaba la hipocresía y las máscaras de moralidad tras las que se ocultaba la corrupción de un arte y de unos sistemas de pensamiento, de sociedad y de política institucionalizados y legitimados por la Iglesia, la burguesía y el poder. De ahí que toda revolución artística tuviera que cumplirse desde la destrucción del propio arte, y esta violencia solamente podía ser realizada a través de la máxima negación. Una negación política, de la cual el arte extraerá, a lo largo de toda la centuria, gran parte de su sentido: la acción política, entendida no como una lucha de poder por los espacios, sino como una transformación positiva de la sociedad, no podía desunirse de la propia acción artística. En este sentido, no es de extrañar el uso que harían los dadaístas de la tipografía, de técnicas gráficas y de los medios de comunicación impresos como difusores del arte: canales políticos de acción y subversión de los códigos.

En última instancia, desde la perspectiva de finales de siglo, el Dadaísmo reveló, casi mejor que ningún otro movimiento, la situación caótica de la cultura europea a principios de siglo, su fermentación, la crueldad de la guerra y la miseria moral de la burguesía: de erigirse en su oposición no pudo evadirse el propio ser del Dadaísmo. La explosión del lenguaje, tanto en las palabras como en las imágenes fue, más que un despropósito de lo absurdo, una necesidad imperiosa de desorden frente a la rigidez insana del orden instituido. La virulencia con que estalló estaba en relación -o era la medida inversa - a la represión de todas las fuerzas vitales de una cultura que, hasta entonces, se había mantenido subterránea, relegada y oculta. Anárquica y transgresora, para liberarla y expresarla los códigos fueron subvertidos.

\section{LA SUBVERSIÓN DE LO TÁCTIL. EL LIBRO DE ARTISTA EN EL FUTURISMO}

Frente a la intensidad de una experiencia vital que exaltaba «el movimiento agresivo, el insomnio febril, el paso gimnástico, el salto peligroso, la 
bofetada y el puñetazo» 12, la escritura y la imagen poco tenían que hacer, excepto convertirse en signos de esa misma experiencia. Pues si «la literatura», según Marinetti "ha magnificado hasta ahora la inmovilidad pensativa, el éxtasis y el sueño", para los artistas futuristas italianos la pintura, hasta que "enarbolara la bandera de la rebelión», no había hecho gran cosa más. Lo que tenía que ser destrozado, estaba claro; aquéllo que debería sustituirlo, también. Y si los dadaístas se debatían en el nihilismo del absurdo y los surrealistas se embarcaban en la imbricación de los sustratos de lo real, los artistas futuristas tuvieron, desde muy pronto, bien definido su credo: un juramento de fe al vitalismo vertiginoso de la máquina, que encontraba su máxima expresión orgiástica en la velocidad. Que este entusiasmo no estaba desprovisto de destrucción, así lo prueba la fácil adhesión de los futuristas a la guerra, condenada por todas las vanguardias, y que vendría a convertirse en uno de los aspectos más polémicos y controvertidos que un movimiento que, en otros aspectos, fue profundamente modernista y brutalmente transgresor. Pues tanto a sus invenciones plásticas como a la libertad de sus palabras, así como a sus insultos, provocaciones y exabruptos, deben sus contemporáneos gran parte de la desestructuración y desacreditación de los lenguajes artísticos, y especialmente en el ámbito del Libro de Artista, la creación, que atravesará fecundamente toda la centuria, del Libro-Objeto y el Libro-Máquina.

La idea futurista de rebelión y revolución difícilmente se conjugaba con el lenguaje y el formato de un libro concebido como pensamiento, información y sucesión narrativa de páginas. Para un arte que buscaba la identificación con la vida, el libro simbolizaba un objeto caduco, que no satisfacía las nuevas necesidades de una acción ligada a una nueva época: la de la industria y la tecnología, las grandes transformaciones sociales y políticas y los descubrimientos científicos. Marinetti, dueño de uno de los primeros automóviles que circuló por Milán, se jactaba en un prefacio escrito en 1914 en Zang Toumb Toumb, de haber utilizado las pruebas de texto para limpiar el carburador de su Fiat. En ello había, según Giovanni Lista, «una voluntad de ridiculizar la imagen del libro como un «instrumento espiritual» que había inspirado Mallarmé» ${ }^{13}$, denunciando el carácter artificial y precario de la escritura en confrontación con la intensidad de lo vital.

Y lo vital debía deshacerse del concepto a través de la sensación, de la tactilidad, de la velocidad, el dinamismo, y la simultaneidad. El «arte tatti-

12 Marinetti, Manifiesto Futurista, Le Figaro, París 1909.

13 Grovanni Lista, «Le Livre Futuriste. De la libération du mot au poème tactile», Ed. Penini. 
le» o "Tattilismo» surge "en función de un viaje abstracto y lúdico de las manos a través de la materia», una "nueva búsqueda psíquica», según Marinetti, que encuentra en las planchas táctiles el soporte adecuado para expresar y corporeizar esta nueva empresa, así como servir de experimentación a los nuevos materiales - metales, cartón, telas, cristal, plásticos- que desacralizarían la pintura como medium. Así, las planchas táctiles eran, según Congiullo, "trozos de cartón rectangulares en general, de 30 a 50 centímetros, sobre los que las dos asistentas de Marinetti fijaban, bajo la dirección del autor, pelusas, esponjas, papel de vidrio, papel de plata, piedra pómez, polvo, etc. En suma, todas las cosas destinadas a ser tocadas, y no a ser vistas, ódas u olidas".

Las planchas táctiles negaban el valor de la visualidad: no en vano eran assemblages, composición de objetos y materiales diversos -muchos de ellos, por no decir todos, extraartísticos- procedentes de los medios más insospechados, entre ellos las basuras, señalando el carácter eminentemente físico y corporal de la obra. Pues así como, más tarde los constructivistas y anteriormente los pintores cubistas habrian de experimentar con el assemblage, sus composiciones atenderían a valores de composición, forma y estructura - como un conjunto organizado- antes que a una experimentación lúdica y fantasmática, "un viaje de las manos a través de la materia».

Marinetti, Soffici, Munari..., crearon planchas táctiles que precedían a las páginas del libro-objeto, suprimiendo a menudo el propio soporte del papel y sustituyéndolo por tela, cuero o metal. En Soudan-Paris una de las más famosas planchas de Marinetti elaboradas en 1920: un cartón de apenas cincuenta centímetros, en cuya superficie se contemplaban, al azar y de forma heterodoxa materiales tan incongruentes y diversos como esponjas, madera, tela, pelo, papel de plata... iy hasta un rallador! Un atentado contra los principios de identidad de la obra artística, que ni siquiera era concebida como tal. Aún más: los elementos con los que las planchas se conformaban, además de negar, como he señalado anteriormente, todo valor estético y visual, actuaban como signos que desestructuraban y destruían toda la síntaxis con que se entendía hasta el momento, como lectura, una obra de arte. ¿Qué legibilidad, qué enfoque de comprensión, para un lector de los años veinte, podía proporcionar "esto"? Ya no era el absurdo, no era el caos ni la búsqueda de un abismamiento revelador de lo oculto: era la organización de otro lenguaje, de un nuevo universo donde la polisemia de las palabras y las cosas era sustituida por materias y objetos que, con códigos diferentes, usurpaban el lugar del propio lenguaje: una verdadera revolución. 
Obras futuristas como las planchas táctiles de Marinetti abrieron el camino a una nueva plástica, aún negándola. Caucho, mica, papel de lija, piel, agujas de fonógrafo, papel, celuloide y otros materiales extraños conformaban, en un soporte inaudito de $9 \times 100$ centímetros, toda una transgresión, pero también un nuevo sentido de la belleza y de la sensación. Por otra parte, la creación de estas planchas táctiles estaba relacionada con la investigación de nuevos materiales industriales, como las hojas de celofán, que abrían la obra a una espacialidad táctil y cinética, basada en un materialismo sensorial. Ello acercaba a los futuristas a otras técnicas como la fotografía y el cine, con sus ritmos secuenciales y su capacidad de simultaneidad. Valores plásticos y dinámicos que se unirían, en gran número de libros de artista, a una intención desacralizadora del libro y de la biblioteca como transmisores de cultura. En 1915, Soffici reunía sus composiciones motlibristas en un volumen en formato de periódico, acentuando con este soporte el carácter modernista de la obra y su efimeridad. Pues, tras su uso, después de ser ojeado - y hojeado- el libro de Soffici era tirado como un periódico. Había en ello una actitud de rebeldía frente a la propia industria del libro como producto, como señala Giovanni Lista: «En sus creaciones, los artistas futuristas respondían así a la aparición de un doble movimiento que amenaza al libro en la época moderna: de un lado, la industria de la cultura, con sus exigencias imperativas de normalización del producto y del trabajo de edición, y por otra parte, el cine, la fotografía y los media de la imagen, que convierten la página escrita en anacrónica».

Al mismo tiempo, la civilización tecnológica e industrial potenciaba una nueva experimentación con los materiales, que culminaría en una estética de la Máquina al tiempo que a una exaltación de su mitología. Surgirá de aquí la experimentación con los libros-máquina, realizados con cubiertas de metales como el estaño, el aluminio y el hierro. La sensualidad de las superficies metálicas, los reflejos luminosos, la lisura y el acabado industrial, el temblor metálico y suavemente sonoro al pasar y tocar las páginas, el peso de los metales, su compacidad y solidez, fueron descubiertos por los artistas futuristas tanto por la presencia corporal y física de su materia como por el culto a la máquina y al objeto industrial. Si «un automóvil de carreras adornado con grandes tubos como serpientes de aliento explosivo..., un automóvil rugidor que parece correr sobre la metralla, es más bello que la Victoria de Samotracia» ${ }^{14}$, un libro metálico adquiere toda la belleza,

14 Manifiesto Futurista 1909. 
la flexibilidad y la potencia de una máquina que, como diría Marinetti, daría a sus aeropoesías «la elasticidad ideal del ala del aeroplano».

Antonio Fornari realiza en 1924 una cubierta de aluminio para Salomé. De aluminio pulido, con un rectángulo de cuero superpuesto, de color violeta, en su interior había una composición geométrica en hilo de aluminio. También D'Albisola realizó las cubiertas en hierro blanco para los poemas y manifestaciones de Marinetti: cada página, en la que entraba en acción el tiempo y el espacio secuencial del libro, recogía las diversas experimentaciones de Marinetti en torno a la palabra y la imagen, tales como los poemas precisos o las palabras en libertad. También D'Albicola, junto con Munari, realizaría otro libro-máquina con poemas e ilustraciones de carácter dinámico y cubiertas de hierro blanco. Se unían así todos los valores de la estética futurista: la máquina y el material industrial, el propio libro como máquina, la libertad de las palabras y su sentido desacralizador (no desprovisto de un carácter panfletario) y la ilustración que recogía todas las premisas del futurismo en torno a la imagen dinámica..., en un objeto táctil, materico y secuencial.

La conexión tradicional entre palabra e imagen se rompe, y ello evidencia y abre una crisis del lenguaje tanto como del uso del libro como objeto de información. Pero esta ruptura de las estructuras, que conmovió de forma violenta la creación artística y literaria de principios de siglo, no puede ser entendida sin el papel que jugaron los mass-media y los canales de propaganda e información, así como los avances en la tipografía, acentuados por la tecnología desarrollada durante la Primera Guerra, como las prensas en off-set. Gran parte de las creaciones artísticas futuristas (y en especial de los futuristas rusos a partir de 1910) se aprovecharían de los nuevos descubrimientos como medio de romper con los soportes y las composiciones del «pasado», negando así la historia y su transmisión, y adquiriendo un carácter político y social en sus manifestaciones públicas desconocido hasta entonces. De aquí, quizás, el tinte panfletario y redentorista de gran número de ilustraciones futuristas, en relación a las ideologías provocadoras y revolucionarias que pretendian transmitir. $Y$ no sólo en periódicos y revistas, sino también en carteles, panfletos y octavillas que, volando en las manifestaciones organizadas en los teatros de las ciudades italianas más populosas, se difundían a un público numeroso y ávido de comunicación y «liberación», entre ellos estudiantes y obreros. Ya en 1909 Marinetti uso las páginas de Le Figaro para la difusión del Primer Manifiesto Futurista, no sin la sorpresa de los lectores frente al tono violento, agresivo y destructor con que estaba escrito: 
"Queremos glorificar la guerra —única higiene del mundo-, el militarismo, el patriotismo, el ademán destructor de los anarquistas, las bellas ideas que matan y el desprecio a la mujer». De tales ideas «gloriosas», conocido es el fin, y como escribiría Kandinsky a Herwarth Walden en 1913 (comunicándole su profundo desacuerdo con la virulencia extremista del Futurismo tanto como con su forma gratuita de dibujar), "vale más no usurparle al tiempo su papel, pues trabaja mejor que nosotros» ${ }^{15}$.

Periódicos y revistas fueron un medio de difusión activa de las ideas y las imágenes futuristas en Italia. Marinetti publicaba en Milán, de 1905 a 1909, la revista Poesía órgano de sus ideas literarias. Una de las revistas más importantes sería Lacerba, fundada en Florencia en 1913 por Papini y Soffici, alrededor de la cual se formó un importante grupo de artistas, y en la que se publicarían numerosos y a menudo polémicos artículos sobre el Futurismo, como Futurismo y Marinettismo, en 1915, duramente acusado por Marinetti, siendo la causa de la ruptura de éste con la revista. Otra revista importante, que establecería el enlace entre los movimientos de vanguardia europeos, sería Noi, fundada en 1917 por Enrico Prampolini y el poeta Bino Samminiatelli. Y ya más cercana al Dadaísmo, en 1920 aparecería Blau, dirigida por el pintor futurista Guilio Evola y Gino Cantarelli y publicada en Mantua hasta 1921. Evola publicó en 1920 en la colección Dadá, dirigida por Tzara, un poema a cuatro voces, La palabra oscura del paisaje interior, y un libro de poemas y grabados en madera titulado Arte abstracto.

Así, la ebullición de poetas, escritores, periodistas y pintores surrealistas se canalizó, en gran medida, a través de la imprenta. Los artistas colaboraron especialmente en las portadas, catálogos, libros y revistas, conjugando en ellas la palabra en movimiento y las experimentaciones tipográficas con un tipo de ilustración caracterizada por su dinamismo y su agresividad, así como por su carácter abstracto, a veces iconoclasta, a menudo exaltado y panfletario, si bien todas ellas marcadas por una investigación plástica que alcanzaba en las cubiertas de Carmelich una relación entre la palabra y la imagen de gran innovación y originalidad.

Poetas y pintores futuristas fueron pioneros en realizar una deconstrucción de la síntaxis y de las estructuras del lenguaje gramatical. Gran

15 Vassily Kandinsky, Cartas a $\mathrm{H}$. Walden del 10 y 15 de noviembre de 1913, Munich. Archivos de “Der Sturm», Nationalgalerie, Berlin 1961. 
parte de los caóticos logros dadaístas se deben a su influencia: algunos de los collages más famosos de Schwitters, ya en 1939, fueron precedidos veinticinco años antes por Les bruits du café nocturne, collage de 1914 de Carrá. La diversidad y el juego tipográfico de las palabras, las frases fragmentadas, el absurdo de un mensaje, la combinación entre superficie pictórica, imagen y escritura y el sistema de analogías que, basado en el Manifiesto sobre Las analogías plásticas del Dinamismo de Gino Severini, en 1913, y El Manifiesto técnico de la Literatura Futurista de Marinetti, hacia 1912, establecía las relaciones cósmicas entre objetos, sensaciones, imágenes y palabras, fueron algunos de los encuentros futuristas más significativos, uno de cuyos motivos principales sería el de la expresión de la sirnultaneidad.

Asimismo, las Palabras en Libertad serían una de las más importantes transgresiones que los futuristas aportarían a la literatura -o llevarían a cabo contra la literatura-. En el Manifiesto técnico de la Literatura Futurista, Marinetti declaró que era necesario destruir la síntaxis tradicional, rechazando asimismo el adverbio, el adjetivo y la conjugación. El verbo debía ser usado en infinitivo y los signos matemáticos $(X=-\%$ :,etc.) ocuparían un lugar fonético y de puntuación. De esta forma, la escritura estaría en función de las sensaciones, de los sonidos y onomatopeyas, de las analogías, del dinamismo y movimiento (a menudo veloz) con que se expresaba el lenguaje, y hasta los mismos espacios en blanco tenían una función. Todo ello, por supuesto, no tenía por qué pasar por el colador del lenguaje tradicional ni por su traducción: simplemente, conformaba otro lenguaje que destruía al anterior.

Parole in Libertá de Marinetti, Buzzi y Govoni fueron expuestas en 1916 en Zurich, en el Cabaret Voltaire: de su conocimiento habrían de beneficiarse Apollinaire, Tzara, Heartfield. Haussman o Schwitters, si bien esta influencia no fue reconocida por los dadaístas. Unos y otros llevarían a cabo una revolución que fusionaría la poesía con el objeto y la imagen. Lo que se presentaba como absurdo y caos no era sino la forma de descubrir, ordenar y apropiarse de una nueva realidad que negaba un sistema de representación del mundo que no estuviera expresado por el propio sujeto.

\section{LA REBELIÓN DE LA SINNTAXIS. EL LIBRO DE ARTISTA CONSTRUCTIVISTA}

«Así como el poeta en su poema une el concepto y el sonido, he intentado crear una unidad equivalente usando el poema y la tipogra- 
fía” ${ }^{16}$. Con estas palabras, El Lissitzky definía uno de los principales motivos - y logros- del Constructivismo: la fusión entre el signo (la grafía) y el contenido (el concepto). No fue casual, pues, que en los talleres constructivistas, tanto rusos como alemanes (en la Bauhaus), se gestara uno de los cambios más drásticos en la tipografía y en las artes gráficas, así como en las ediciones de revistas, carteles y libros. Y así como futuristas, dadaístas y surrealistas se habían dedicado violentamente a arrasar los códigos y a erosionar los modelos heredados, los artistas constructivistas sobrepasaron el nihilismo de la destrucción y la orgía: absorbiendo todo el valor de la transgresión, se dedicaron a «ordenarla», a con-figurarla: a construirla. Pues la revolución de los objetos y de las formas ya estaba consolidada, se trataba, en esta nueva fase, de articularla, de darle cuerpo y hacerla, técnicamente, com-prensible. Trasladarla, del plano de la posibilidad, al de la realidad. $Y$ de ésta, a lo social.

Y ¿qué hay más social que la letra, la palabra y la escritura? Y si ello es pura comunicación, no lo es menos el espacio de la página, lugar creativo donde los lenguajes adquieren su visualidad y definen su presencia: se hacen trans-misibles. Esta transmisión, vital para el artista constructivista, del lenguaje se canaliza a través de la publicación: poetas, arquitectos, tipógrafos, diseñadores, fotógrafos y artistas participarán en un proyecto común. Unir el arte con la función, la forma con lo colectivo, lo poético con la técnica.

Fueron los artistas rusos (futuristas y constructivistas) los primeros en explorar las posibilidades tecnológicas de la imprenta, conduciéndolas, como instrumento, a la difusión de ideas. La politización del artista, tan radical en la Rusia zarista y prerrevolucionaria, fue el motor que indujo a una experimentación vertida hacia lo social, abriendo el acceso de los artistas a las imprentas. La tecnología significaba para el artista ruso un acercamiento del arte a la sociedad, que se imbricaba en la Utopía política de transformarla... a través del Arte. Según Martha Wilson, «El experimento tipográfico en la página les permitía una experiencia visual al mismo tiempo que daban expresión a sus ideas políticas».

16 LISSITZKY-KÜPPERS, SOPHIE: "El Lissitzky, Life-Letters-Text», Thames and Hudson, London 1967, págs. 94-108. 
En la URSS revolucionaría, a partir de 1917, se produjo una fuerte actividad de los artistas rusos en los talleres. Poetas y artistas como Maiakowsky, El Lissitzky, Kandinsky, Chagall, Malávich, Pevsner o Gabo trabajaban en el mundo de las imágenes a través de la propaganda y de libros, pósters, carteles y revistas, impulsando la tipografía y el diseño de libros y cubiertas. De aquí surgiría uno de los libros más interesantes y logrados de la poética constructivista, «Dlia Glosa» (1923), producto de una colaboración común entre Maiakowsky y El Lissitzky. El libro fue creado siguiendo criterios poéticos y musicales, estrechamente relacionados con la experimentación tipográfica. Concebido como una "composición», en dos colores, proveía al lector de un índice alfabético de los signos utilizados, para hacerle legible el poema. Pero era la dinámica de las construcciones gráficas lo que dominaba la página. Los poemas variaban desde el tono militarista y poético al estilo más lírico. «Dlia Glosa» supuso una perfecta unión de lo plástico y lo poético en un solo lenguaje.

Sin embargo, la rigidez del sistema comunista pronto ahogaría, a partir de 1925, los caminos libres de la experimentación. Como es sabido, el Estado comenzó a exigir a los artistas que abandonaran los presupuestos vanguardistas en pro de un acercamiento al lenguaje funcional y al discurso de propaganda política del régimen. El presupuesto destinado a los talleres gráficos y artísticos fue desviado para otros fines más «urgentes» en un país que necesitaba consolidar su revolución tanto como hacer uso social de todos sus recursos económicos. $Y$ en ello, lo artístico no tenía cabida, sino era doblegándose a la más primaria necesidad funcional. Así, Malévich terminó diseñando pantalones y estufas, muchos artistas acabaron en la cárcel, Maiakowsky se suicidó y los que pudieron huyeron, como El Lissitzky, Kandinsky, Chagall o los hermanos Pavsner y Gabo, hacia otros países donde pudieran desarrollar su arte con libertad. $Y$ entre éstos, fue Alemania, y sería la escuela de la Bauhaus la que recogería sus ideas y su trabajo.

Los talleres gráficos de la Bauhaus estaban destinados a la experimentación tipográfica, a la encuadernación de libros, al diseño de portadas y páginas, a la publicación de revistas y folletos relativos a las actividades de la Escuela y a la impresión de técnicas de grabado, litografía y xilografía especialmente, destinada a la ilustración y a la relación entre palabra e imagen tanto en las páginas como en las portadas. Creado en principio para la impresión de trabajos gráficos, estuvo bajo la dirección de Lyonel Feininger y la supervisión técnica de Carl Zaubitzer. En ellos trabajaban tanto los alumnos como los profesores y todos los artistas que participa- 
ban en la Bauhaus: Moholy-Nagy, Kandinsky, Klee, Gropius o Mondrian: las publicaciones fueron un vehículo para transmitir sus ideas sobre teoría y práctica de las diversas artes. A través de ellas se difundieron las ideas de la Gelstat, de la arquitectura constructivista, de la pedagogía del arte o de la fotografía: «Malerei, Photographie und Film» de Moholy-Nagy fue una de las publicaciones más importantes sobre fotografía de la época, e iría seguida de una exposición histórica, «Film und Foto», realizada en 1929 en Stuttgart. El diseño de las portadas respondía a un mismo principio y a una uniformidad, decidida por Moholy-Nagy, difiriendo ligeramente en las composiciones, generalmente de carácter constructivo y muy pocas veces figurativo, que eran realizadas por diversos artistas como Theo van Doesburg, el mismo Moholy-Nagy, Gropius o Adolf Meyer. El color era utilizado en la mayoría de los diseños, alternando los números, las líneas, las superficies y los títulos en diferentes colores básicos según los números, como el rojo, azul, amarillo y a veces gris. Los «Bauhausbücher» fueron diseñados en 1924 y publicados por la Albert Langen Press en 1925, alcanzando su edición hasta los años 30 .

Los trabajos tipográficos introdujeron en el mundo artístico una sistematización necesaria para, como he señalado anteriormente, "ordenar" el caos lingüístico al mismo tiempo que confirmar la ruptura con la ilustración y el lenguaje decimonónico. Por un lado, se «rompió" con la herencia de la letra gótica, tan común en la época, creando un tipo de letra mayúscula basada en la claridad y la construcción esencial de curvas y líneas en un ritmo uniforme y geométrico. Fue esta geometrización, impuesta como un principio racionalista y universal, una de las principales características de los libros de artista constructivistas: en ellos, forma y función iban unidas en pro de una ordenación plástica y de una claridad visual. Asímismo, la relación entre las formas, los signos y los espacios se convirtió, no sólo en un motivo estructural, sino también en uno de los principios básicos de percepción, impulsados por la teoría de la Gelstat. Así, los libros de artista constructivistas, tanto como la tipografía, se convirtieron en un vehículo de experimentación tan valioso para la teoría del arte como para su difusión.

Igualmente importante fue la encuadernación de libros en los talleres. El trabajo, llevado a cabo por los alumnos bajo la dirección de maestros como Otto Dorfner, consistía tanto en la encuadernación y el diseño de portadas como en la impresión de litografías, xilografías, etc., como ilustraciones para el interior de las páginas, así como un trabajo tipográfico en la creación de las letras. Muchos de ellos siguieron caminos experimentales, otros se basaron en modelos góticos o heredados del Romanticismo. A menudo encuadernados en piel, los libros de la Bauhaus nunca rompieron, como hi- 
cieron futuristas y dadaístas, el formato clásico del libro como soporte. La sucesión de páginas, rota por el libro-objeto o las planchas táctiles, fue rigurosamente seguida en el libro constructivista, más interesado en la formación y creación rigurosa y esencial de un lenguaje plástico que en los excesos incontrolables, mágicos y abismales de lo poético.

\section{CONCLUSIÓN}

La ruptura con la identidad de un lenguaje clásico concebido como Totalidad fue una de las principales «empresas» llevadas a cabo por las Vanguardias de principios de siglo. Destruida la relación (heredada) entre palabra e imagen, signo y significado, advino una explosión y un caos que encontraba, precisamente en el desorden, su maquinaria infernal, su aparato de desacralización de la cultura. $Y$ si, a través del azar, de la imaginación, de la de-formación y del fragmento, se llevó a cabo este fenómeno de des-trucción y erosión violenta de los códigos, también es cierto que dió lugar a una creación de una magnitud que conmocionaría la propia identidad del arte.

Así, lo que, epidérmicamente podía parecer un caos, pronto reveló una estructura interna, una poética y una coherencia capaz de articular signos y significados con nuevas lecturas y lenguajes. Ello confluyó, y tuvo uno de sus canales principales, en las publicaciones y Libros de Artista: poetas y pintores transformaron la palabra en imagen y la imagen en poesía. El Arte, que nunca ha dejado de ser Filosofía, se desprendió de las convenciones de la realidad para plantear una nueva visión de lo real desde la interioridad del artista tanto como de unas exigencias sociales y políticas que implicaban la transformación de una colectividad: palabra e imagen adquirieron una dimensión revolucionaria desconocida.

Las revistas y los Libros de Artista permitieron una difusión de los mensajes artísticos inaudita, y ello fue debido gracias a las nuevas tecnologías y a una industria tipográfica que aumentaría y abriría formas diferentes a la producción. Pero también los artistas investigaron en los talleres, y sus experimentaciones dieron lugar a nuevas concepciones y juegos visuales que se insertarían en la propia sociedad. Las imagenes vanguardistas se popularizaron a través de periódicos, folletos, revistas, libros y carteles, a menudo con un alto contenido político y eminentemente subversivo. Relegar la profunda transformación del arte de las primeras vanguardias al Museo de la pintura y de la escultura sin tener en cuenta las palabras e imagenes surgidas de la imprenta significa ignorar las intenciones y las preocupaciones de una revolución artística que convulsionaría el siglo. 